\title{
Transatlantica
}

Revue d'études américaines. American Studies Journal

\section{An Interview with Steven Millhauser}

\section{Marc Chénetier}

\section{OpenEdition}

Journals

Édition électronique

URL : http://journals.openedition.org/transatlantica/562

DOI : $10.4000 /$ transatlantica.562

ISSN : 1765-2766

Éditeur

AFEA

\section{Référence électronique}

Marc Chénetier, «An Interview with Steven Millhauser », Transatlantica [En ligne], 1 | 2003, mis en ligne le 24 mars 2006, consulté le 29 avril 2021. URL : http://journals.openedition.org/transatlantica/562 ; DOI : https://doi.org/10.4000/transatlantica.562

Ce document a été généré automatiquement le 29 avril 2021.

\section{(c)}

Transatlantica - Revue d'études américaines est mis à disposition selon les termes de la licence Creative Commons Attribution - Pas d'Utilisation Commerciale - Pas de Modification 4.0 International. 


\title{
An Interview with Steven Millhauser
}

\author{
Marc Chénetier
}

1 This interview was conducted by e-mail between November 20th and December 10th 2003, in the wake of Steven Millhauser's readings in Paris

2 Marc Chénetier: Could I begin by asking you how you see the place the collection The Knife-Thrower occupies in your work, not in terms of chronology, even though its composition is not itself entirely chronological, but in terms of its relative importance, thematically and/or formally?

Steven Millhauser: I'm almost superstitiously reluctant to comment on the possible "importance" of any element of my work, as if by doing so I were trespassing on terrain properly reserved for critics. But in the case of this collection, I do have the sense of a formal fact that may be worth mentioning. As stories began to accumulate during the 90s, I was aware that many of them made use of a plural narrator-the "we" of the title story and of some half dozen others. The use of "we" is, of course, hardly my invention. It's used more than once by Kafka, most notably in "Josephine the Singer, or The Mouse Folk," to say nothing of the famous opening of Madame Bovary, where the very first word is "Nous." It's also used by the chorus in Greek tragedy, although there you have a visible group speaking together-sometimes as "we," sometimes as "I." In any case, I found myself increasingly drawn to this pronoun, partly because it allowed me to enact the drama of an entire community set against a person or group that threatens it, and partly because the pronoun felt new and exciting, a pronoun that didn't drag in its wake one hundred billion stories, as in the case of an "I" or a "he." It strikes me as a barely explored pronoun, full of possibilities, and I'm certainly not done with it.

4 One of Beckett's narrators reports that as a child he learned the names of the days of the week. And the child thinks: "Only seven!" I sometimes feel the same way about the personal pronouns... Only three!-or perhaps: Only six! I'd invent a fourth person, if I could. Short of that, the scarcely explored "we" remains deeply interesting to me.

5 MC: You seem to take it for granted there is a terrain "properly reserved for critics." Which would it be? 


$$
\text { in evaluation. A writer of fiction may have analytic or evaluative gifts, but the act he's engaged }
$$
in is essentially synthetic.

MC: Might one say that the use of the "we," passing the buck, so to speak, to a collective voice, is one way for the narrator to avoid the issue of moral choice or, to put it differently, to avert or dissolve responsibility for this or that particular interpretation of the events related? what interests me about the "we" is something quite different. What interests me is the way moral indecisiveness or questioning may be given more weight or significance by attaching itself to a multiple being. A single narrator might have multiple interpretations of an event, or might try to evade moral choice in numerous ways, but the same kind of uncertainty in an entire community becomes public, societal, even political, and carries a different weight. I would argue that the moral wavering of the "we" in "The Knife Thrower" is more disturbing than the moral wavering of an " $I$ " would have been, or disturbing in a different way.

MC: For all this, the "we" of "The New Automaton Theater", for example, "cohabits" with an "I", who reports on that "we"...

SM: One of the things I find fascinating about the "we" is the way it can slip easily in and out of "I." When that happens, as in this story and "The Sisterhood of Night," the "we" becomes different from the "we" of a story (like "The Knife Thrower") that doesn't contain an "I." In these double-pronoun stories, the "we" is revealed as having its origin in an " $I$ "-the "we" is a mask behind which a particular narrator speaks for an entire group. Or you could say that the "we" is grounded in an "I." In a "we" story that doesn't slip into "I," the "we" is more difficult to account for. It acts rather like a chorus, a mysterious plurality chanting in unison. You can, however, imagine an undramatized single narrator, emitting the words but speaking on behalf of a community. How can one resist a pronoun so supple and ungraspable?

11 MC: Would you consider The Knife-Thrower as somewhat "darker" than preceding collections, and, if so, why should this turn have been taken?

SM: If a story is an artifact composed of a certain amount of darkness and a certain amount of light, I suppose it's true that this collection is somewhat darker than the earlier ones. The reasons for this are obscure to me, though, so far as I can tell, it has nothing to do with some darkening sense of the human condition, or any such ponderous thought. What I look for in a work of art is something that might be called an expansion of being, a sense of mysterious exhilaration, and this has little to do with the quality of darkness in a work, but rather with the arrangement of elements, the elaboration of a significant design. The darkness is surely there, but it's in the service of something else, which I think of as celebratory.

MC: Would you care to try and define this mysterious "something else?"

14

SM: I see you won't let me get away with anything! I intended nothing mystical or mystifying here. I meant only that art is connected in my mind-in my body-with a sense of enhancement, of radical pleasure, of affirmation, of revelry. Darkness is the element against which this deeper force asserts itself. It may even be that this force deliberately seeks out darkness, in order to assert itself more radically.

MC: In this context, did you deliberately undertake the composition of Enchanted Night as a sort of "pause" in your work, a more serene, appeased version of themes and motifs exploited in the previous book? 

the previous book, but it's also true that this wasn't my only way of thinking about it. I was searching for a form that allowed me to use many different voices, to use a host of pronouns. The conception of the work was musical-a theme and variations on a summer night. In a sense, Enchanted Night was an elaboration of "Clair de Lune." I confess that the word "pause" makes me a little uneasy. It seems to suggest that serious effort was somehow interrupted for the sake of this book. But that wasn't my sense of it at all, not for a moment. I hurled myself into that little book as into everything I write-as if it's the only thing I've ever written, as if there could never be anything else.

MC: I didn't mean that Enchanted Night had less intensity, urgency or necessity, but that it read as much more appeased, as if staging characters and situations that had, so to speak, been rather "defused", rid of their more potentially explosive tensions, operated in the midst of a less stormy blue.

SM: Fair enough. I deliberately set out to soothe a number of troubled characters, to give them respite. I had in mind the spirit of something like A Midsummer Night's Dream. A slow movement in a violin sonata. Adagio cantabile.

MC: This being so, would you care to explain what it was you wanted them to have respite from?

SM: From the confusion and sorrow and disappointment of their lives. Haverstraw is a failed writer who has never left his childhood house, Laura is restless and virginal and assaulted by dangerous vague longings, Coop drinks too much and feels that his life since high school has gone downhill, Danny is upset about not having a girlfriend, the mannequin is trapped in her elegant careful pose, the woman who lives alone talks to herself out of sheer loneliness, Pierrot is desperate for a sign from Columbine, and even Janet is anxious and wants from the night something the night doesn't usually bring. In the lovely Ben Jonson song from which I borrowed the book's epigraph, the poet addresses Diana the huntress, goddess of the moon:

Lay thy bow of pearl apart

And thy crystal-shining quiver.

Give unto the flying hart

Space to breathe, how short soever.

In Enchanted Night, I gave the flying hart-the restless heart-a

little space to breathe. Day will come soon enough.

21 MC: Since you mention this "flying hart," what kind of continuity or difference would you discern between the sort of levitation that occurs at the end of "Clair de Lune" and the overall theme of "Flying Carpets?" And how do they connect, in your mind-or contrast-with the dialectics of "Balloon Flight, 1870?"

SM: The ascents in all three stories are expressions of spiritual elevation, of a casting off of earthly or material things. But the differences are crucial. In "Clair de Lune," the final ascent is a kind of ecstatic soaring, a disappearance into regions of bliss. In "Flying Carpets" the ascent is a deliberately undertaken adventure, which the boy carries to a forbidden extreme-he soon becomes fearful of losing touch with the familiar objects of his world. The return to earth is presented as joyful, though at the end of the story there's a suggestion that the ascent has become a forgotten wonder, an adventure now unimaginable, a movement of spirit to which the mundane boy no longer has access. This contrast between realms of air and earth is carried into "Balloon Flight, 1870," where it's made even more explicit. My narrator begins his flight with a clear, practical, indeed political objective, but he soon finds himself in unearthly regions that

Transatlantica, 1 | 2003 
threaten to break his bonds with human things. He returns to earth with a feeling of gratitude and joy, like the boy in "Flying Carpets" before the final two paragraphs of that story. I suspect there are other shades of difference and similarity, but these are the ones that come to mind.

MC: You said earlier that "In a sense, Enchanted Night was an elaboration of "Clair de Lune'." Could you say in what sense and, more particularly, what you feel had been "underexplored" in the story, needed "elaboration" or, to phrase the question in another way, what differences between these two creations were important to you?

SM: It's an elaboration in the sense that although the decor is much the same-moon, blue night, wandering-the novella widens the geography, increases the number of characters, lengthens the time, complicates the mood. But I wasn't driven to Enchanted Night by any sense that "Clair de Lune" was somehow underexplored. I do sometimes feel that something is insufficiently explored in a story-for instance, the history of the early years of Sarabee in "Paradise Park," which later developed into the story of Martin Dressler-but in this instance the impulse derived from something else. What I wanted most to do, in the novella, was experiment with many points of view. It's almost as if I wished to attempt in stricter, more lyrical form my own miniature version of a Dos Passos novel. Exactly what impelled me to choose a summer night is mysterious even to myself, though summer nights abound in my work, "Clair de Lune" simply being a recent instance.

MC: Two stories, at least, in The Knife-Thrower, seem to partake of a logic different from the imaginative developments of your previous work: "A Visit" and "Kaspar Hauser Speaks." Would you care to comment on what I see as the imaginative, formal, "reversed" challenges they represent?

SM: I was very much aware of violating my own usual procedure while writing "A Visit." There are essentially two ways of presenting the fantastic in a story. You can begin in the everyday, familiar world and move gradually in the direction of the unfamiliar, so that the reader can barely detect where the line is crossed, or you can introduce the fantastic suddenly and eruptively. The second method is the method of Gulliver's Travels (every detail before the introduction of the six-inch Lilliputians is scrupulously realistic), of the explosive opening of Kafka's Metamorphosis, and of any British ghost story (in which a familiar world is suddenly disrupted by the supernatural). By temperament and conviction, I much prefer the first method, the slow elaboration of a quotidian world that veers gradually toward the unquotidian, the improbable, the impossible. In "A Visit," however, the logic of the story required a different approach. In fact I resisted it for a long time, since I dislike the crude melodrama of a sudden impossible eruption. But it began to fascinate me, almost as a kind of challenge. The problem, as I saw it, was to outrage the reader's trust, and then seduce the reader into believing what can't be believed. All this is quite apart from other considerations, such as the fairy-tale theme of the frog (who in this case turns into a beautiful creature without changing).

MC: Would you, thereby, mean that this "visit" is less an epiphany or visitation than a gradual getting acquainted, a progressive acceptance of the odd, the different, the "other side" of the "real"?

SM: Yes, I like that way of putting it. But it's also true that the story leads to a moment, near the end, very much in the style of a classic epiphany. You might say that "A Visit" owes a structural debt to a familiar kind of realistic story, while introducing into the body of the text an element associated with fairy tales.

29 MC: But I haven't let you answer the question on the "difference" that seems to characterize "Kaspar Hauser"... 

different logic from the other stories. Most of my stories include solitary figures, who in one way or another are posed against a community (the knife thrower against the audience, the narrator of "A Visit" against the friend and the frog, Heinrich Graum against the other masters and the town, Sarabee against the usual world of amusement-park owners), and Kaspar Hauser is the most solitary of them all. But you're quite right that the movement in the story is crucially different. In other stories, a solitary figure-or, in "The Dream of the Consortium," a solitary institution-generally moves in a direction that grows more and more extreme. Here, Kaspar longs to be less extreme, to move in the opposite direction, to blend in with the crowd. Logic demanded it. Kaspar's experience, indeed his entire nature, is so extreme that the only direction in which he can move is toward the familiar and everyday. I would argue that such a longing only emphasizes his apartness.

31 MC: What, then, in "Kaspar Hauser" is the relative importance of, or the connection between his explanation of "how things looked" to him before (accounting for the "real world," in other words, for example what a candle is) and his gradual realization that his perceptions, emotions and attitudes should become "normal?" Doesn't the "poetry" of his condition depend on his not understanding what the world is like?

SM: Yes, it's absolutely essential for him to begin by not understanding what the world is like. His radical estrangement, which for everyone else constitutes the "poetry" of his condition, is precisely what drives him toward the normal. The normal or average is usually granted a certain respect in my stories, is even celebrated, but in this story it is associated solely with mediocrity, with the loss of individual perception. Kaspar craves mediocrity the way average people crave the exotic. Verlaine's Gaspard Hauser asks: "Qu'est-ce que je fais en ce monde?" My Kaspar answers: I am learning the art of disappearance...

MC: Earlier, you mentioned your desire to eschew "such ponderous questions." Do Ihappily - hear in this an invitation to avoid at all costs anything that might be construed as the symbolic import of motifs, objects and situations, anything that might arrest the movement of the text and the imagination in favor of a stable world view of any kind?

training and temperament I believe that the text is primary, that the reader must not bring to the text anything that isn't actually there. I have an aversion to what you call "symbolic import" because it seems a way of smuggling into a text illegal goods. But though I don't concern myself with hidden symbolic meanings, or a consistent world view, I draw back from something in your question that seems to make me forbid such speculation altogether. It may well be that a writer is drawn to a particular cluster of motifs and objects and situations, that such a cluster defines that writer's imaginative response to the world and distinguishes him usefully from other writers, and that the cluster therefore suggests or points to a larger meaning that can be defined. I have no objection to interpretations of that kind, so long as they derive rigorously from what is actually in the work.

MC: What is the ratio, in the collection, of historical detail and invented, imaginary material, and to what ends do you have recourse to accurate historical detail or shift over to imagined facts and references?

SM: The proportion varies. In stories based on historical events, such as "Balloon Flight, 1870" and "Kaspar Hauser Speaks" there is a fairly large amount of accurate historical detail, though even in such pieces the details are in the service of unhistorical, which is to say fictional, ends. In "Kaspar Hauser," details such as the tower, the candle, the window, the elderberries, are all

Transatlantica, 1 | 2003 
taken from the extremely precise accounts left by Anton von Feuerbach and Georg Friedrich Daumer, but the speech itself is entirely invented-the historical Kaspar Hauser had a rudimentary grasp of language and could never have delivered a speech so rhetorically sophisticated. The historical details in "Balloon Flight, 1870" are taken from histories of the Franco-Prussian War and the brilliantly detailed journal of Edmond de Goncourt, but the thoughts and feelings of the narrator are of course my invention. But even in stories that require no research, stories that are, so to speak, entirely invented, many details of setting are based on my memory of particular streets and houses and rooms-and because memory is itself a form of history, these stories too may be said to have an historical basis. In some cases a clearly "invented" story-say, "Paradise Park," with its series of increasingly improbable amusement parks-springs from my reading about an historical event, in this case the development of the three Coney Island amusement parks at the turn of the century. Sometimes in a story imagined without the aid of research, such as "The Sisterhood of Night," I might add a small historical detail, which only a few readers may notice. In that story, for example, I named one of the girls Mary Warren. It's a very commonplace name, which anyone might have, but it happens also to be the name of one of the girls at the Salem witch trials.

MC: Would you care, as an obvious follow-up, to comment on the reasons for your fascination with the world of adolescence?

SM: What's fascinating about adolescence is that it's an in-between state. It feels a tug in two directions: back toward the completed world of childhood, from which it is permanently banished, and forward toward the unknown realm of adulthood, which it both craves and fears. Because it's an in-between state, adolescence is fluid, unformed, unsettled, impermanent-in a sense, it doesn't exist at all. Fiction conventionally presents adolescence as a time of sexual awakening, but for me it feels like the very image of spirit in all its restless striving.

MC: One suggestion I was tempted to make in the book I wrote on your work was that one founding, permanent crisis in your texts consists in the contradictory desire to find a form for dreams and things and a refusal to see this necessary form solidify into anything permanent, a permanent struggle between form and dissolution. How widely have I erred?

SM: Not widely, not narrowly, not at all. One thing I learned from your book-and I learned lots of things-was how often I write about dissolution. It hadn't struck me before. Why this continual return to images of disappearance, of fading away, of dissolving? It must be that dissolution is the necessary other side of permanence, its logical contradiction. It's also a fact in the world: the loveliest snowman melts away, civilizations crumble, galaxies die. Against this universal principle of dissolution, the urge for un-dissolution, for permanence, asserts itself. Form is the response of the spirit to the experience of dissolution.

41 MC: Is your insistence on dream and the imagination connected with a concern for any kind of transcendence?

SM: No and yes. If by "transcendence" you mean something religious or mystical, then the answer is no. But "transcendence" is a tricky word. Its roots suggest a climbing-across, a rising-above, a going-beyond. In this sense, dream and imagination are nothing but acts of transcendence, since they carry us beyond the limits of immediate sensation. In the same way, memory is also an act of transcendence. But I would make a distinction between secondary imagining and dreaming, and primary imagining and dreaming. The secondary form is whimsical, ignorant, a little bored, a little frivolous-it seeks only distraction. The primary form, though playful like all acts of mind, is radically serious. It seeks to go beyond immediate sensation because it doesn't believe that sensation fully accounts for the astonishing, 
ungraspable event called the world. In this sense, dream and imagination are methods of investigating the nature of things, they are precise instruments for exploring reality. But enough, and more than enough. For someone who prefers silence, I've been talking far too much. It must be your fault.

MC: Let me be guilty all the way, then: your texts often refer to "something dubious" in the desire of the imagined spectators of "The Knife-Thrower," or "Paradise Park," to "forbidden passions" that "cannot be named." Pointing as they seem to do to a fascination for the erotic and the deadly, should these mentions, however, be read more widely to suggest a collective desire for further "unspeakable practices," or are they, less topically, meant to underline the somber side of any imaginative act?

SM: Both; but the second especially. Imagination has the violence and danger of all powerful things. Reason continually comes up against limits, it's in fact an acknowledgment of limits, but imagination is unstoppable, it wants to smash limits out of sheer exuberance. Its cry is always the same: More! More! The brightest, most playful act of imagination casts a dark shadow.

MC: A question that may lead us back to your use of the "we" in the volume at hand has to do with the room left for the reader in front of your characters' rather imperial dreams? What is your most ardently wished for reaction on his/her part?

SM: Another madly impossible question. I think the adventure I'd wish for a reader is the opposite of the one told by Kaspar Hauser. That is, I'd wish the reader, in the course of falling into one of my stories, to grow more and more estranged from the familiar, until by the end of the story he or she, if only for a moment, sees the world as a mysterious and surprising place. After all, our nervous systems are arranged for practical ends-we see what's immediately useful to us and ignore the rest. In this sense, art is a method of destruction. It turns our attention away from the useful, it allows us to see things usually obscured by habit-it invites us to witness the thrilling strangeness of the world.

47 MC: Thank you, dear Steven, for your good will, patience and precision while answering my "madly impossible questions." After all, you are an expert concerning the "madly impossible"... and the temptation was great.

\section{AUTEUR}

\section{MARC CHÉNETIER}

Université Denis-Diderot, Institut Universitaire de France 